\title{
China IS014001 Certification Overview and Literature Review
}

\author{
Junxia Li \\ School of Management, Jinan University, Guangzhou, China \\ Email: ljxann@qq.com
}

How to cite this paper: Li, J.X. (2019) China ISO14001 Certification Overview and Literature Review. Journal of Human Resource and Sustainability Studies, 7, 108-120. https://doi.org/10.4236/jhrss.2019.71008

Received: March 8, 2019

Accepted: March 26, 2019

Published: March 29, 2019

Copyright $\odot 2019$ by author(s) and Scientific Research Publishing Inc. This work is licensed under the Creative Commons Attribution International License (CC BY 4.0).

http://creativecommons.org/licenses/by/4.0/

\begin{abstract}
This paper reviews the empirical literature based on the Chinese background from 1998 to 2018 to summarize the motivations and consequences of enterprises adopting the ISO14001 standard. Specifically, this paper sorts out and comments on the internal and external driving factors of Chinese enterprises adopting ISO14001 certification and the actual impact of implementing certification on the economy and the environment, and puts forward the inadequacies of existing research and future research directions.
\end{abstract}

\section{Keywords}

ISO14001, Environmental Management System Certification, Sustainable Development, Literature Review

\section{Introduction}

In recent years, industrial development and economic globalisation have allowed developing countries such as China to achieve unprecedented economic growth over the past two decades. A majority of international manufacturers have set up their manufacturing facilities in Asia. This industrial migration has brought considerable economic opportunities to developing Asian countries, but the toxic substances such as waste gas, waste liquids and emissions, and the extensive economic growth pattern of high energy consumption and high pollution caused by the modernization of industrial and agricultural production are worrying. The serious ecological problems such as pollution and depletion of natural resources cannot be ignored. Developing countries are facing the challenge of sustainable economic and environmental development, and China, as the largest economy among them, is no exception.

Due to the relative scarcity of resources, poor environmental living conditions 
and increased international pressure, developing countries have taken action to seek an effective approach to solve these problems [1]. Environmental management system certification is a useful tool to improve the sustainable development of enterprises and China has begun to promote various environmental management principles in various manufacturing companies and industries to improve their environmental performance and expand their suppliers and customers [2].

Environmental management system standard, also known as ISO14001 standard, is a series of international standards formulated by international standardization organization to standardize the environmental behavior of various organizations, promote the organization to save resources, energy, reduce and prevent pollution, improve the level of environmental management, improve environmental quality, and promote the sustainable and healthy development of economy. As a useful tool to improve corporate sustainability, China has greatly promoted environmental protection after equally adopting ISO14001 standard. However, due to the economic and operational obstacles caused by high cost and implementation complexity, such environmental practices have not been widely adopted [3]. Therefore, it is of practical significance to study the adoption and implementation of Chinese ISO14001 standard for promoting win-win development of economy and environment, and the promotion of ISO14001 certification in developing countries.

The existing literature on environmental management system certification is mainly concentrated in developed countries and the results of these studies may not be applicable to developing countries such as China. This paper takes China, the largest economy of developing countries, as the research object, to help better understand the situation of Chinese enterprises adopting ISO14001 standards, so as to provide reference for other developing countries.

This paper is divided into five parts. The first part introduces the research background and the situation of Chinese ISO14001 certification. The second part introduces the literature review of empirical research, mainly from two aspects of motivations and consequences. The third part summarizes the findings and analyses the shortcomings of current research. The fourth part is a summary of the full text. The fifth part elaborates the future research direction.

\section{IS014001 in China}

At present, the ISO14000 series of standards have been adopted by many countries. The GB/T24000-ISO14000 environmental management series standard adopted by China has been implemented on April 1, 1997 and its core standard is the ISO14001 standard. Article 4 of the "Regulations on Certification and Accreditation of the People's Republic of China" in 2003 stipulates that "the State shall implement a unified certification and accreditation supervision and management system". That is to say, China shall implement a unified management system by the State Accreditation and Accreditation Regulatory Commission.

As of January 2019, with the great encouragement of the Chinese government, 
over 210,000 organizations have passed the ISO14001 certification and obtained the ISO14001 certificate. The number of certifications is significantly higher than that of other countries or regions, ranking first in the world and still growing every year. It is foreseeable that China will maintain its leading position in the world in ISO14001 certification for a long time in the future.

The rapid development of environmental management system certification has aroused widespread debate among scholars and managers and ISO14001 certification has become the object of many empirical studies. Although the number of Chinese certifications is among the highest in the world, due to the difficulty in obtaining certification data, the empirical research on ISO14001 certification is still in its infancy, lagging behind developed countries such as Europe and the United States. Therefore, this paper analyzes the current research status of Chinese environmental certification by reviewing the empirical research on Chinese environmental management system certification published between 1996 and 2018, and seeks evidence support for the country's modern ecological sustainable development.

\section{Literature Review}

According to the research theme, this paper collects the literature on the main databases of CNKI, Econ Lit, JSTOR, Science Edrect, Springer and Google Scholar with the keywords of "China", "ISO14001", "Environmental Management System" and "Environmental Certification". Based on the existing empirical literature in the Chinese background, the following contents are summarized from driving factors and actual consequences of adopting ISO14001 certification.

\subsection{Motivation for IS014001 Certification}

In terms of theoretical research, scholars believe that the driving factors of ISO14001 certification are complex, involving all levels of factors inside and outside the enterprise. However, in empirical research, the conclusions on the internal and external driving factors have not reached consensus. At present, Chinese empirical research on the driving factors of environmental management system certification is in its infancy, which is mainly divided into internal driving factors and external driving factors.

1) External Driving Factors

The existing research based on Chinese background has mostly discussed the external driving factors of adopting ISO14001 certification in the following four aspects:

a) The first factor is the impact of customer pressure and demand or other interest groups, which is mainly manifested in the customers' pursuit of green environmental protection and international trade requirements. For example, Christmann and Taylor (2001) find that companies with multinational ownership and products exported to developed countries are more likely to adopt environmental certification through a survey of 101 companies in Shenzhen and 
Shanghai [4]. Wang and Li (2004) show that the goal of adopting ISO14001 certification is to meet the requirements of the head office and related parties such as customers or contractors [5]. Yin and Ma (2009) find that Chinese ISO14001 certification is mainly concentrated on export-oriented industries and international trade has indeed increased the adoption of ISO14001 standards through the pressure of international green customers, that is, the pursuit of international customers in the global product chain may be the key factor behind the adoption of ISO14001 standard [6].

b) The second factor is related to the external image of the company, which sends signals to potential consumers by emphasizing the environmental problems of the company or the pressure exerted by the public administration. For example, Yang and $\mathrm{Hu}$ (2008) examine the influence of green logo on consumers' brand trust and purchase intention through questionnaire surveys. The purpose of adopting green certification is to increase consumers' trust in products and brands produced by enterprises and consumers' purchase intention [7]. Qi et al. (2011) use panels data of ISO14001 certifications in various provinces of China from 2004 to 2008, and find that sending signals to foreign customers and community stakeholders plays a leading role in encouraging the promotion of ISO14001 certification [8].

c) The third factor is the impact of formal and informal institutional pressures. For example, Zhang and $\mathrm{Bu}$ (2015) use the data from 30 provinces (cities and districts) in China from 2004 to 2011 to test the relationship between embedded global value chains and informal environmental regulations and ISO14001 certification of Chinese enterprises. They find that informal regulation transmitted through global value chain is beneficial to the improvement of environmental protection behavior of Chinese enterprises, and that domestic public environmental attention and exporting to Europe and North America have a positive effect on the adoption of ISO14001 certification [9]. Zhu et al. (2012) survey 377 Chinese manufacturers of six major industrial groups in Suzhou, Dalian and Tianjin in 2006, and found that normative, compulsory and imitative international institutional pressures were the driving factors for adopting ISO14001 certification, TQEM and ecological auditing [10]. In addition, the higher the certification rate of the city where the company is located, the more likely the company tends to voluntarily adopt the ISO14001 environmental management system certification [11].

d) The fourth factor is to improve the environmental performance of enterprises. Fryxel (2002) uses the Hong Kong sample to find that improving corporate reputation, seeking to reduce costs and improving environmental performance are the reasons for companies to adopt certification. To enhance reputation and reduce costs, companies can adopt more effective methods to assess environmental factors and Impact, but no additional improvements have been found in environmental management system of enterprises adopting certification for improving environmental performance [12]. 
2) Internal Driving Factors

Relatively speaking, there are few studies on internal drivers factors. Only a few studies have confirmed the existence of internal drivers, mainly including management's environmental awareness, internal organizational influence and reducing corporate costs [11] [12]. For example, Lu et al. (2015) use the questionnaire data of 1268 industrial enterprises in China and find that managers' environmental awareness has a significant positive impact on the voluntary ISO14001 certification of enterprises, and the pressure of government environmental supervision acts a role in the enterprise's certification behavior through the management's awareness [11]. Yang and Zhou (2005) use the questionnaire data of large and medium-sized industrial enterprises in China to find that managers' environmental orientation, learning ability, internal organizational experience and tradition have a significant positive impact on corporate environmental certification behavior, but the external driving forces including coercive force, normative force and imitative force had no significant impact [13].

3) External and Internal Driving Factors

There are also some literatures summarizing the internal and external driving factors. For example, Zeng et al. (2003) do a questionnaire survey on Chinese construction industry, which shows that the main motivation for adopting ISO14001 certification is to enter the international construction market. Other motivations include standardization of internal operational environment management procedures, social recognition, customer image and better corporate image [14]. Chan et al. (2006) issue ISO14001 certification questionnaires to the Chinese hotel industry in Hong Kong, Macau, Shenzhen and Guangzhou, and find eight incentives for ISO14001 certification: 1) corporate governance, 2) ISO benefits, 3) top management, 4) Legislation, 5) market trends, 6) trade barriers, 7) customers and 8) competitors. In addition, fears of international trade barriers to different environmental performance standards will prompt hotel operators to adopt ISO14001 standards [15]. Zhan (2006) empirically finds out that the external driving force for adopting ISO14001 certification includes four factors: government mandatory driving force, market driving force, cultural and social expectation driving force and industry driving force, while two factors are contributed to the internal driving force: promoting organizational certification intention and affecting organizational certification ability [16].

\subsection{Consequences of IS014001 Certification}

Most scholars have found that environmental certification can bring the following effects to the enterprise: market share expansion (improvement of export revenue), cleaner production, efficient operation, reduction of resource consumption, improving profitability, enhancing competitiveness of products or services, improving corporate image and raising environmental awareness (Kollman and Prakash, 2002; Bansal and Bogner, 2002; Link and Naveh, 2006). However, in the background of developing countries, the exploration of the ac- 
tual impact of ISO14001 certification is still rare. The research on the actual impact of environmental management system certification in China is mainly from the economic, environmental and other perspectives.

1) Economic Perspective

a) International Trade or International Competitiveness

For example, Xie (2001) analyzes the impact of certification on Chinese export trade and export enterprises, believing that the implementation of ISO14001 standard will be conducive to further improving the competitiveness of Chinese export enterprises and their products in the international market and promoting the growth of international trade [17]. Wang (2002), after objectively analyzing the dual nature of "non-tariff trade barriers" and "protecting the global ecological environment" of "green barriers", believes that encouraging enterprises to adopt ISO14000 certification is an effective way for enterprises to break through "green barrier" and enter international market smoothly [18].

b) Corporate Performance or Corporate Value.

Whether ISO14001 certification can enhance corporate value has always been a hot topic in academic circles. One opinion is that ISO certification can enhance corporate value. For example, Wang and Li (2004) make a questionnaire study on corporate ISO14000 certification, and found that an important purpose of adopting ISO14000 certification is to increase sales revenue and market share [5]. Wang and Yuan (2004) study the relationship between environmental certification and stock excess returns and find that on the certification announcement day, Chinese stock market would produce very small positive excess returns, and the impact of environmental certification on stock excess returns declined with the increase of company size [19]. Wang and Lin (2006) specifically explore the relationship between ISO14000 certification and enterprise value growth. According to the situation of listed companies in China, ISO14000 certification has a positive impact on the growth of shareholders' rights and interests, and sales performance has also been significantly improved after certification. Especially for companies in environmentally sensitive industries, shareholders' rights and interests increase more prominently after certification [20]. Geng and Xiao (2006) explore the impact of ISO14000 certification on the export of Chinese enterprises, and show that enterprises with ISO14000 certification can achieve a super-long growth rate of export revenue relative to the same industry and other enterprises without certification. Over time, foreign shareholder factors have a significant positive impact on the super-long growth rate of export revenue of enterprises with certification [21]. Wang (2007) empirically tests that the economic performance of enterprises after ISO14000 certification has been significantly improved, which shows the possibility of win-win between environmental performance and economic performance, and the realization of this win-win also benefits from the improvement of the corporate own organizational capacity [22]. Wu (2015) make an empirical analysis on the listed companies of A-share heavy pollution industry in Shanghai Stock Exchange of China from 
2009 to 2013, which shows that ISO14001 certification will bring positive effects on the growth of main business income and owner's rights and interests of enterprises, and promote the growth of enterprise value. That is, ISO14001 certification provides an effective environmental management model for enterprises, and encourages enterprises to actively implement low-carbon economy and circular economy, therefore enterprises can achieve a win-win situation of improving environmental performance level and increasing financial performance [23].

Another view is that ISO14001 certification is not a significant factor affecting enterprise value. $\mathrm{Fu}$ (2015) surveys the relationship between environmental management system and enterprise performance of Chinese manufacturing enterprises through questionnaires, and finds that ISO14001 certification was not a significant factor affecting enterprise performance. Different implementation levels determined the significant difference in enterprise performance. That is, the higher degree of integration of environmental certification in daily application, the better enterprise performance will be. However, because environmental certification occupies a large amount of enterprise resources, it may cause the decline of economic performance in the short term [24].

2) Environmental Perspective

The discussion of the relationship between ISO14001 certification and environmental performance also has two distinct perspectives. One view is that environmental certification can significantly improve corporate environmental performance, and the other view is that environmental certification has no significant impact on environmental performance. For example, Li (2009) makes an empirical study on 27 listed companies in ferrous metal smelting and calendering industry in China, which shows that the size of the company and the certification of ISO14000 environmental management had a significant positive correlation with environmental information disclosure [25]. Qi et al. (2012) discuss the environmental performance after ISO14001 internalized in enterprise management practice and managers' awareness, and find that ISO14001 plays a significant role in promoting enterprise environmental performance, which also confirms that the resources, capabilities and some heterogeneous characteristics of enterprises may be the key factors of affecting enterprise environmental performance after ISO14001 certification [26].

However, Yin and Ma (2009) find that ISO14001 certification in China had little impact on improving environmental performance, and if there were improvements in environmental performance, it would only be beyond the bottom line of environmental regulations [6].

3) Other Perspective

Some papers also discuss the actual changes brought by ISO14001 certification to enterprises in detail, including changes in production efficiency, waste recycling, resource saving, clean production and other corporate own behavior, as well as the external impact of enterprises. 
For example, Matouq et al. (2000) investigate the implementation process of ISO14001 in Chinese certified enterprises and find that the ISO14001 environmental management system has a significant impact on the corporate daily environmental activities and performance. Recovery and utilization, natural resource consumption and pollutant discharge have been better managed, and pollutants have been reduced in some cases. The study shows that the main objectives of the environmental management system are to enhance the public image of enterprises, enhance the environmental awareness of employees, improve EMS within the company, improve environment and performance within the company, and improve relations with government offices and local citizens. In addition, Matouq et al. believe that ISO 14001 environmental management system is a promising tool for building better partnerships among the three major stakeholders, government, local citizens and enterprises [27].

Zeng et al. (2003) make an investigation and analysis on the implementation of ISO14001 environmental management in Chinese construction enterprises and the results show that after the implementation of ISO14001 environmental management in enterprises, the utilization efficiency of raw materials, production efficiency and waste recycling have been significantly improved [14]. Zeng et al. (2005) use 108 enterprise data to analyze the environmental benefits of enterprises after implementing ISO14001 standard, and find that $81 \%$ of the surveyed enterprises have made great progress in clean production, $55 \%$ of the surveyed enterprises have saved resources and reduced waste, $37 \%$ and $46 \%$ gain more trust from customers and improved corporate image [28].

Liu (2010) investigates the melamine pollution incident in dairy industry in 2008 in order to inspect the effectiveness of ISO9000 quality management system certification, ISO14001 environmental management system certification, HACCP hazard control and critical control point certification in preventing and controlling melamine pollution. The results show that ISO9000 quality management system certification, HACCP hazard analysis and critical control point certification do not play a significant positive role in reducing the risk of melamine pollution, while ISO14001 environmental management system increase the risk of melamine pollution [29].

Zeng (2013) takes 348 manufacturing enterprises in Guangdong Province of China as an empirical research object to explore the impact of energy saving and emission reduction on technological innovation of enterprises. The results show that reducing energy consumption has a positive impact on the output rate of new products, but whether enterprises adopt ISO14000 certification has no significant impact on the output rate of new products [30].

McGuire \& William (2014) use survey data from manufacturing enterprises in China to test the adoption model of ISO14001 certification and the implementation model of environmental regulation by using SURBP method, which shows that enterprises with ISO14001 certification will abide by the government's environmental regulation more strictly [31]. 
In summary, this part collects relevant literatures by searching keywords, and summarizes the ISO14001 empirical research based on the current Chinese background. It is mainly divided into two subsections. The first subsection summarizes the motivation for adopting ISO14001 certification from the internal and external aspects of the enterprise. The second subsection summarizes the consequences of adopting ISO14001 certification from the perspectives of economy and environment. The next section will discuss in detail the current status and shortcomings of current research results.

\section{Findings and Analysis}

At present, the empirical research on environmental ISO14001 certification of Chinese background is still in the developing stage. The exploration of the motivation of environmental certification is mainly based on the internal and external factors of enterprises. Most scholars agree that the external factors are mainly divided into four points: The first is the impact of customer pressure and demand or other interest groups, mainly reflected in the customer's pursuit of green environmental protection and international trade requirements. The second is the factors related to the external image of enterprises send signals to potential consumers by emphasizing the impact of corporate environmental problems or public administration pressure. The third is the impact of formal and informal institutional pressures, such as environmental regulation or social and cultural expectations. The fourth is to improve the environmental performance of enterprises. Relatively, internal factors mainly include management environment orientation, learning ability, organizational internal experience and tradition, and reducing enterprise costs.

The consequences of environmental certification based on the Chinese background are discussed from different perspectives such as economy and environment. Existing studies mainly support the conclusion that ISO14001 certification can improve the corporate economic and environmental performance, and only a few scholars hold different views on this. The improvement of corporate economy by ISO14001 certification is mainly manifested in breaking through trade barriers, enhancing international competitiveness, increasing sales revenue and market share, which is also the economic motivation for more and more enterprises to adopt certification nowadays. In addition, some literatures have investigated the essential changes brought by ISO certification to enterprises through questionnaires, mainly reflected in the improvement of production efficiency, resource saving and the change of corporate image.

Compared with empirical studies abroad, this paper argues that the existing research in China still has the following shortcomings:

1) In terms of research methods, foreign research mostly adopts questionnaire survey, experimental research and empirical research methods, while Chinese research mostly adopts normative demonstration methods, and less in-depth empirical research on data at the enterprise level. 
2) Compared with foreign related research, China has less research on environmental certification and lacks international comparison.

3) The discussion of ISO14001 certification in China pays more attention to suppliers and customers, while ignoring the role of government, employees and other stakeholders in the practice of environmental certification.

4) More attention is paid to the external driving factors of environmental certification, while neglecting the internal driving factors such as management cost and organizational strategy.

\section{Conclusion and Discussion}

Whether at present or in the future, economic and environmental sustainability is still a difficult problem for all countries in the world, especially for developing countries like China. The contribution of this paper is to sort out the relevant research on the motivations and consequences of adopting ISO14001 certification in China, to help understand the research status of Chinese ISO14001 certification and to help developing countries like China to promote ISO14001 certification and achieve economic and environmental sustainable development. Existing research shows that the adoption of ISO14001 not only helps to break through trade barriers, improve the economic efficiency of enterprises, but also helps to improve the clean production methods and corporate images, especially for trade-oriented enterprises. But in most developing countries, the contribution of ISO14001 certification to international exports, corporate value, and corporate environmental performance remains a controversial topic. Some scholars have come to different conclusions, which may be caused by different national conditions, or based on different choices of indicators, models, and methods. Especially, there is no unified evaluation index to measure the environmental performance of enterprises.

It is worth noting that there are still some obstacles in the adoption of ISO14001 certification, such as higher certification costs, financial burden, low returns of most companies, lower management concepts, lack of professional environmental management personnel and weak enforcement of laws, which are still obstacles for enterprises in developing countries to promote ISO14001 certification [14] [32]. The government should take the lead in encouraging training, providing financial support, improving the legal framework, and providing guarantee for enterprises to promote ISO14001 certification [14].

\section{Implications for Future Research}

Future research needs to pay more attention to the causes and consequences of environmental management system certification in the background of developing countries, which are embodied in three directions:

Firstly, we can make an effective summary and clarification of the driving factors and economic consequences of ISO14001 certification in developing countries based on the research conclusions drawn from the social background 
of developed countries.

Secondly, besides these enterprises participating in the international market are active in adopting ISO14001 certification, the number of ISO14001 certification in many industries in China is increasing rapidly.

Therefore, we can make a comparative analysis of ISO14001 certification in different industries and different value chain modes, and explore its different impacts and differences, so as to provide theoretical support for seeking an effective mechanism to promote corporate environmental governance.

Thirdly, it is necessary to analyze the strategic motivation and actual effect of ISO14001 certification in developing countries in the light of specific background, because developing countries' enterprises may symbolically adopt ISO14001 certification like other developed countries' enterprises, rather than pursuing substantive improvement [33]. The research in this field will help to provide reasonable evidence for the recent proposition of ecological modernization in developing countries such as China.

\section{Conflicts of Interest}

The authors declare no conflicts of interest regarding the publication of this paper.

\section{References}

[1] Blackman, A., Lahiri, B., Pizer, W., Planter, M.R. and Piña, C.M. (2010) Voluntary Environmental Regulation in Developing Countries: Mexico's Clean Industry Program. Journal of Environmental Economics and Management, 60, 182-192. https://doi.org/10.1016/j.jeem.2010.05.006

[2] Zhu, Q. and Sarkis, J. (2006) An Inter-Sectoral Comparison of Green Supply Chain Management in China: Drivers and Practices. Journal of Cleaner Production, 14, 472-486. https://doi.org/10.1016/j.jclepro.2005.01.003

[3] GSCC (Global Supply Chain Council) and GXS (2009) Green Supply Chain China Survey [Online]. GSCC, Shanghai. http://www.supplychains.com/attachments/files/3864/Green_Survey-digital.pdf

[4] Christmann, P. and Taylor, G. (2001) Globalization and the Environment: Determinants of Firm Self-Regulation in China. Journal of International Business Studies, 32, 439-458. https://doi.org/10.1057/palgrave.jibs.8490976

[5] Wang, L.Y. and Li, W. (2004) Cost and Benefit of Environmental Management System Certification and Audit: A Survey of Enterprises Implementing International Standard ISO14000s. Doctoral Dissertation, Shanxi University of Finance and Economics, Shanxi.

[6] Yin, H. and Ma, C. (2009) International Integration: A Hope for a Greener China? International Marketing Review, 26, 348-367. https://doi.org/10.1108/02651330910960825

[7] Yang, X.Y. and Hu, X.H. (2008) Study on the Influence of Green Certification on Brand Trust and Purchase Intention. Exploration of International Economy and Trade, 12, 66-70.

[8] Qi, G.Y., Zeng, S.X., Tam, C.M., Yin, H.T., Wu, J.F. and Dai, Z.H. (2011) Diffusion of ISO 14001 Environmental Management Systems in China: Rethinking on Stake- 
holders' Roles. Journal of Cleaner Production, 19, 1250-1256.

https://doi.org/10.1016/j.jclepro.2011.03.006

[9] Zhang, S.F. and Bu, M.L. (2015) Embedded in Global Value Chain, Informal Environmental Regulation and ISO 14001 Certification of Chinese Enterprises-Empirical Research based on Interprovincial Panel Data 2004-2011. Finance and Trade Research, 26, 70-78.

[10] Zhu, Q., Cordeiro, J. and Sarkis, J. (2012) International and Domestic Pressures and Responses of Chinese Firms to Greening. Ecological Economics, 83, 144-153. https://doi.org/10.1016/j.ecolecon.2012.04.007

[11] Lu, J.Y., He, W.L., Wang, T.M. and Liu, Y. (2015) External Pressure, Self-Recognition and Enterprise Standardized Environmental Management System. Economic Science, No. 1, 114-125.

[12] Fryxell, G.E. and Szeto, A. (2002) The Influence of Motivations for Seeking ISO 14001 Certification: An Empirical Study of ISO 14001 Certified Facilities in Hong Kong. Journal of Environmental Management, 65, 223-238. https://doi.org/10.1006/jema.2001.0538

[13] Yang D.N. and Zhou C.H. (2005) The Driving Force of Enterprises' Voluntary Adoption of Standardized Environmental Management System: Theoretical Framework and Empirical Analysis. Management World, 2, 85-95.

[14] Zeng, S.X., Tam, C.M., Deng, Z.M. and Tam, V.W. (2003) ISO 14000 and the Construction Industry: Survey in China. Journal of Management in Engineering, 19, 107-115. https://doi.org/10.1061/(ASCE)0742-597X(2003)19:3(107)

[15] Chan, E.S. and Wong, S.C. (2006) Motivations for ISO 14001 in the Hotel Industry. Tourism Management, 27, 481-492. https://doi.org/10.1016/j.tourman.2004.10.007

[16] Zhan, S.Q. (2006) Research on Driving Forces and Countermeasures for the Adoption of ISO 14001 Environmental Management System. Master's Thesis, Zhejiang University, Zhejiang.

[17] Xie, G.E. (2001) The Impact of ISO14000 on China's Export Trade. International Economic and Trade Exploration, 5, 73-76.

[18] Wang, S.Y. (2002) From the Dual Nature of Green Barriers, We Should Take Measures. China Soft Science, No. 8, 35-38.

[19] Yuan, Y. and Wang L.Y. (2004) Stock Price Effect of Environmental and Quality Management Certification. Economic Science, 26, 59-71.

[20] Wang, L.Y. and Lin, X.C. (2006) ISO14000 Environmental Management Certification and Enterprise Value Growth. Economic Science, No. 3, 97-105.

[21] Geng, J.X. and Xiao, Z.D. (2006) Empirical Study on Export Effect of ISO 14000 Certification-Evidence from China's Capital Market. Exploration of International Economy and Trade, 1, 22-25.

[22] Wang, J. (2007) Economic Analysis of Enterprise Voluntary Environmental Regulation based on ISO14000 Environmental Management Certification System. Doctoral Dissertation, Xiamen University, Xiamen.

[23] Wu J.F. (2015) Environmental Information Disclosure, Financing Cost and Enterprise Value Growth. Doctoral Dissertation, University of Foreign Economics and Trade, Beijing.

[24] Fu, M.Y. (2015) Study on the Mechanism of the Effect of ISO 14001 Environmental Management System on Enterprise Performance. Doctoral Dissertation, China Jiliang University, Zhejiang. 
[25] Li, J. (2009) An Empirical Study on the Influencing Factors of Environmental Information Disclosure of Listed Companies in China. Doctoral Dissertation, Huazhong University of Science and Technology, Wuhan.

[26] Qi, G., Zeng, S., Li, X. and Tam, C. (2012) Role of Internalization Process in Defining the Relationship between ISO 14001 Certification and Corporate Environmental Performance. Corporate Social Responsibility and Environmental Management, 19, 129-140.

[27] Matouq, M. (2000) A Case-Study of ISO 14001-Based Environmental Management System Implementation in the People's Republic of China. Local Environment, 5, 415-433.

[28] Zeng, S.X., Tam, C.M., Tam, V.W. and Deng, Z.M. (2005) Towards Implementation of ISO 14001 Environmental Management Systems in Selected Industries in China. Journal of Cleaner Production, 13, 645-656.

https://doi.org/10.1016/j.jclepro.2003.12.009

[29] Liu, C.Q., Sun, Y.Y., Long, W.J. and Poplar Competition (2009) Management and Regulation: Empirical Analysis of Influencing Factors of Melamine Pollution in Dairy Enterprises. Management World, 12, 38-45.

[30] Zeng, P., Deng, T.Z. and Wu, X.J. (2013) Energy Conservation, Emission Reduction and Technological Innovation: Empirical Evidence from Enterprises in Guangdong Pearl River Delta Region. Economic System Reform, 1, 132-140.

[31] McGuire, W. (2014) The Effect of ISO 14001 on Environmental Regulatory Compliance in China. Ecological Economics, 105, 254-264. https://doi.org/10.1016/j.ecolecon.2014.06.007

[32] Khanna, M. and Liao, Y. (2014) Globalization and Voluntary Environmental Management in Developing Countries. Frontiers of Economics in China, 9, 138-163.

[33] Boiral, O. (2007) Corporate Greening through ISO 14001: A Rational Myth? Organization Science, 18, 127-146. https://doi.org/10.1287/orsc.1060.0224 